\title{
The Effect of Kangaroo Mother Care in Increasing Body Weight and Temperature in Premature Infants: Meta-Analysis
}

\author{
Ines Ratni Pravitasari'), Vitri Widyaningsih"), Bhisma Murti') \\ 1)Masters Program in Public Health, Universitas Sebelas Maret \\ ${ }^{2)}$ Faculty of Medicine, Universitas Sebelas Maret
}

\section{ABSTRACT}

Background: Preterm birth is the leading cause of death in toddlers by $7.5 \%-12.5 \%$ in various regions of the world. Premature is one of the causes of low birth weight and is a factor that increases the risk of hypothermia. Kangaroo Mother Care is a powerful and easyto-use method for improving the long-term health and well-being of premature babies. This study aimed to estimate the average effect of Kangaroo Mother Care therapy on increasing body weight and temperature of premature infants.

Subjects and Method: This was a metaanalysis and a systematic. The articles used were obtained from PubMed, Science Direct and Google Scholar. The inclusion criteria used were full text articles with the Randomized Control Trial (RCT) design, the study subjects were premature infants, the treatment provided was Kangaroo Mother Care with a comparison of conventional care, weight and temperature assessment of premature infants using standard scales and thermometers, articles published in English. The PICO research problems are as follows. Population $=$ premature babies. Intervention $=$ Kangaroo Mother Care. Comparison $=$ Conventional Method Care. Outcome= weight and temperature of premature infants. This study used the effect size (Standardized
Mean Difference). Meta analysis was performed using RevMan 5.3 with a Random Effect Model. Results: A total of 15 articles conducted a meta-analysis review of this study. The metaanalysis of 11 articles showed that Kangaroo Mother Care increased weight gain in premature infants compared to conventional method care (Standardized Mean Difference $=0.54$; 95\% $\mathrm{CI}=0.17$ to $0.92 ; \mathrm{p}=0.004)$. Meta analysis on 4 articles showed that Kangaroo Mother Care increased the temperature in preterm infants higher than the conventional method of care, statistically not significant (Standardized Mean Difference $=0.48 ; 95 \% \mathrm{CI}=-0.23$ to 1.19 ; $\mathrm{p}=0.190$ ).

Conclusion: Kangaroo Mother Care is effective in increasing body weight and temperature in premature infants

Keywords: Kangaroo care, skin-to-skin contact, weight, temperature, preterm infant

\section{Correspondence:}

Ines Ratni Pravitasari. Masters Program in Public Health, Universitas Sebelas Maret. Jl. Ir. Sutami 36A, Surakarta 57126, Central Java. Email: inesratnip@gmail.com. Mobile: +6285649507909.

\section{Cite this as:}

Pravitasari IR, Widyaningsih V, Murti B (Year). The Effect of Kangaroo Mother Care in Increasing Body Weight and Temperature in Premature Infants: Meta-Analysis. J Matern Child Health. 05(05): 563-578. https://doi.org/10.26911/thejmch.2020.05.05.10.

\section{Journal of Maternal and Child Health is licensed under a Creative Commons}

Attribution-NonCommercial-ShareAlike 4.o International License.

\section{BACKGROUND}

Preterm birth is the birth of a baby before 37 weeks of gestation and occurs in $7.5 \%$ $12.5 \%$ in various regions of the world. Preterm birth reaches the highest rate in developing countries (Taheri et al., 2018).
Globally, prematurity is the leading cause of death in toddlers and preterm birth rates are increasing in almost all countries(Liu et al., 2016). 
Infants with low birth weight are infants born weighing $<2,500$ grams (Bailey, 2012). Preterm birth is one of the reasons for LBW because it has not reached the term of gestation. LBW accounts for $60 \%$ to $80 \%$ of all neonatal deaths. The global prevalence of LBW is $15.5 \%$, which is about 20 million LBW babies born every year (Bailey, 2012).

Premature and low birth weight are factors that increase the risk of hypothermia (Mullany et al., 2010). Hypothermia is defined by the World Health Organization (WHO) as a core body temperature which is less than $36.50 \mathrm{C}$ (McCall et al., 2018). In premature babies, temperature regulation tends to be worse due to the inability to shiver and immature thermal regulation due to the amount of brown fat that allows heat production by thermogenesis that is not fully formed (Bailey, 2012).

Kangaroo Mother Care is the care of premature infants by positioning the baby skin-to-skin with the mother. It is a powerful and easy-to-use method for improving the long-term health and well-being of premature babies (WHO, 2003). Based on research conducted by Swarnkar and Vagha in 2016, babies with the Kangaroo Mother Care technique achieved significantly better growth at the end of the study (significantly higher body weight, length and head circumference). In addition, fewer babies in the Kangaroo Mother Care group suffered from hypothermia, hypoglycemia, and sepsis (Swarnkar and Vagha, 2016). The concept of Kangaroo Mother Care has been adopted and modified according to the settings and needs in developing and developed countries (WHO, 2003). Kangaroo Mother Care is one of the simple and acceptable methods to mothers and can be continued at home(Swarnkar and Vagha, 2016).
Several studies have been conducted to determine the effect of kangaroo mother care, one of them is the research of Ramani et al., (2018) entitled Kangaroo Mother Care for the Prevention of Neonatal Hypothermia: A Randomized Controlled Trial in Term Neonates, this study stated that the proportion of neonates with moderate or severe hypothermia did not differ between KMC and control groups at 1 hour after birth. However, another study by Santhi and Kokilavani (2013) entitled Effect of Kangaroo Mother Care on Neonatal Temperature and Weight among Newborns, said that KMC leads to weight gain and better temperature. Based on this study, it seems that some research results are not conclusive, so a comprehensive study of various primary studies involving the effect of Kangaroo Mother Care on the increase in body weight and temperature of premature infants is needed. The data obtained will be analyzed using systematic review and metaanalysis by synthesizing the results of studies conducted to reduce bias.

\section{SUBJECTS AND METHOD \\ 1. Study Design}

This study is a systematic review and metaanalysis study. The articles used in this study were obtained from several databases including PubMed, Science Direct, and Google Scholar. The keywords for finding articles are as follows: "kangaroo mother care" AND "weight" AND "neonatal outcomes" AND "temperature" OR "skin to skin contact" OR "kangaroo care" OR "kangaroo method"AND "Randomized Controlled Trial"

\section{Inclusion Criteria}

The articles included in this study were full text articles with the Randomized Controlled Trial (RCT) design, the study subjects were preterm babies, the care provided was Kangaroo Mother Care with a 
comparison of Conventional Method Care, weight and temperature assessment of premature babies using scales and standardized thermometer, and the articles used in the study were published in English

\section{Exclusion Criteria}

The articles published in this study were the provision of Kangaroo Mother Care for less than 1 hour per day, the results of the study did not include the complete mean and standard deviation, and the treatment provided was Kangaroo Mother Care with additional treatments.

\section{Operational definition of variables}

The article search was carried out by considering the eligibility criteria defined using the PICO model. The population in this study were premature infants. Intervention was in the form of Kangaroo Mother Care. Comparison was in the form of Conventional Method Care. And the outcome was in the form of weight and temperature of premature infants.

Kangaroo mother careis skin-to-skin contact between mother and baby after birth for at least 1 hour per day.
Weight gain is the amount of premature baby's weight gain after Kangaroo Mother Care treatment.

The temperature increase is the increase in the baby's temperature after the Kangaroo Mother Care treatment.

\section{DataAnalysis}

Data processing was carried out by the Review Manager (RevMan 5.3) by calculating the effect size and heterogeneity to determine which study models were combined and formed the final meta-analysis result.

\section{RESULTS}

The process of searching for articles by searching through a database with journals can be seen in Figure 2. The final result of the article review process showed that there were 15 articles that fulfill the quantitative requirements for a meta-analysis of the effect of Kangaroo Mother Care on increasing body weight and temperature in premature infants, which were divided into 2 categories according to the dependent variable used, among others: weight gain and temperature

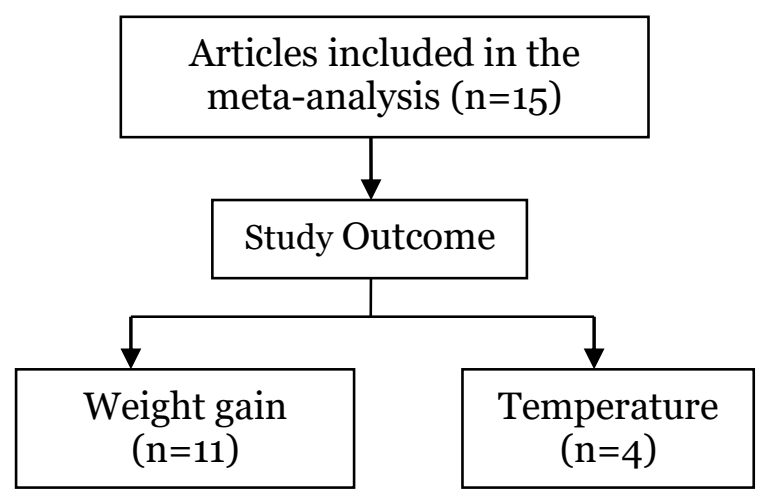

Figure 1. Articles included in the meta-analysis

Figure 3 shows the areas where articles were taken according to the inclusion criteria. Articles obtained from 4 conti- nents, namely Asia, North America, Australia and Africa. 
Pravitasari et al./ The Effect of Kangaroo Mother Care in Increasing Body Weight

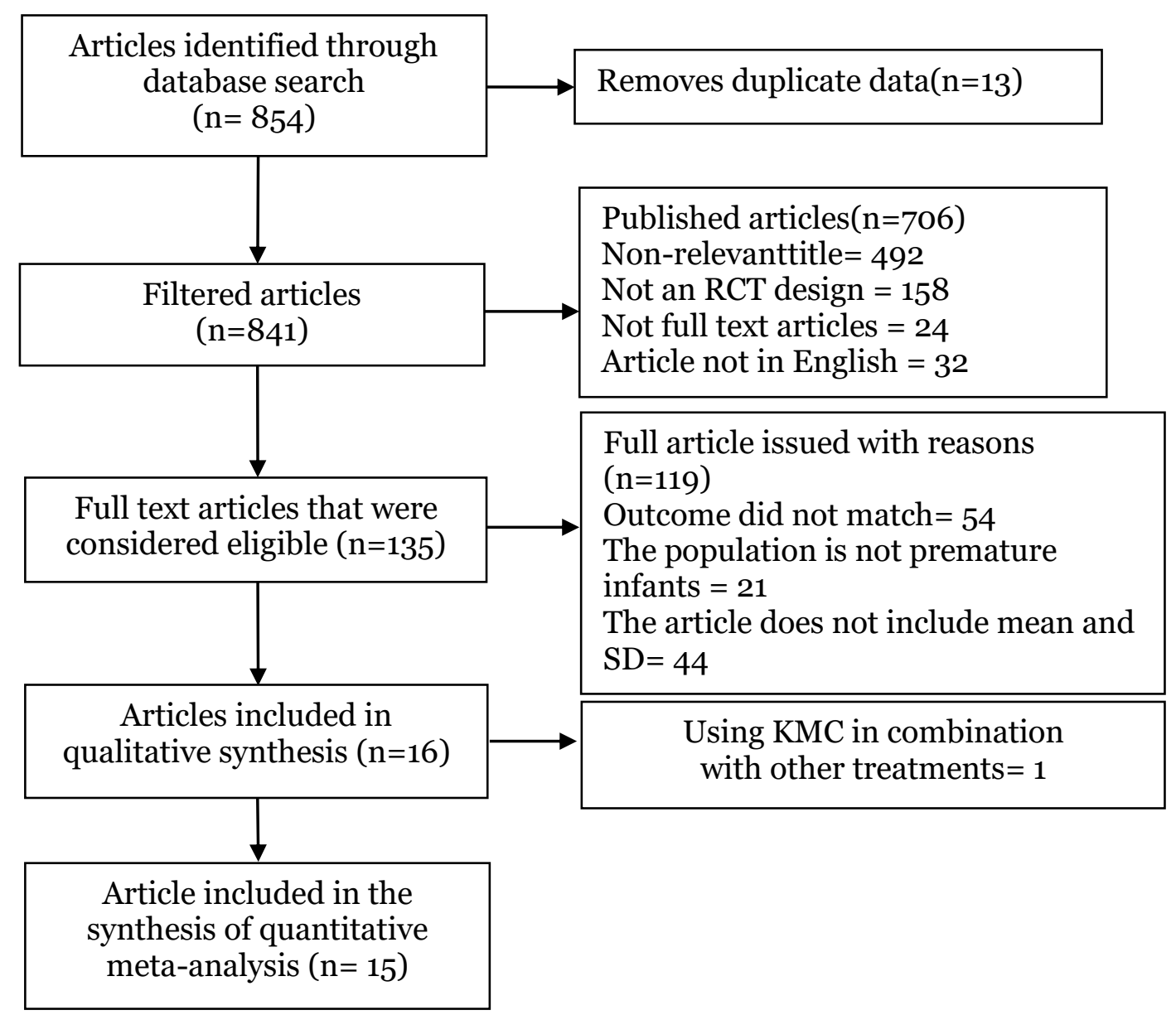

Figure 2. PRISMA flow diagram
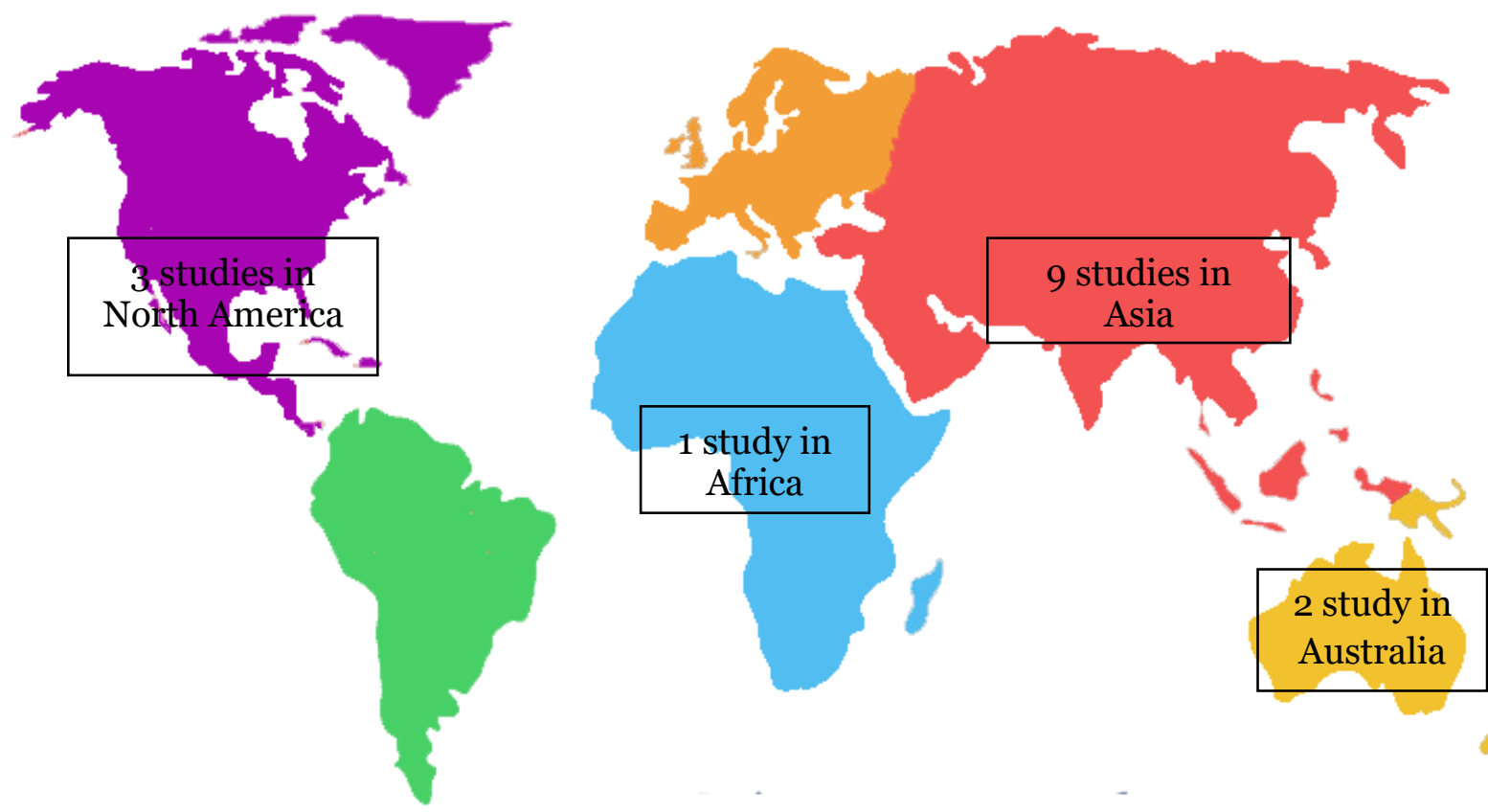

Figure 3. Map of the study area on the effect of kangaroo mother care on increasing body weight and temperature in premature infants 


\section{Summary Source}

\section{a. Weight Gain}

Table 1.Primary study descriptions included in the meta-analysis of the Effect of Kangaroo Mother Care on Weight Gain in Premature Infants

\begin{tabular}{|c|c|c|c|c|c|c|c|c|c|}
\hline \multirow{2}{*}{ Title } & \multirow{2}{*}{ Author } & \multirow{2}{*}{$\begin{array}{c}\text { Year/ } \\
\text { Country }\end{array}$} & \multirow{2}{*}{$\begin{array}{c}\text { Study } \\
\text { Design }\end{array}$} & \multicolumn{2}{|c|}{ Total Sample } & \multirow{2}{*}{$\begin{array}{l}\text { Populati } \\
\text { on }\end{array}$} & \multirow{2}{*}{ Intervention } & \multirow{2}{*}{ Comparison } & \multirow{2}{*}{ Outcome } \\
\hline & & & & KMC & Control & & & & \\
\hline $\begin{array}{l}\text { Effect of kangaroo } \\
\text { mother care on phy- } \\
\text { sical growth, breast- } \\
\text { feeding and its } \\
\text { acceptability }\end{array}$ & $\begin{array}{l}\text { Gathwala } \\
\text { et al., }\end{array}$ & $\begin{array}{l}2010 / \\
\text { India }\end{array}$ & RCT & 50 & 50 & $\begin{array}{l}\text { Premature } \\
\text { infants } \\
<1800 \mathrm{~g}\end{array}$ & $\begin{array}{l}\text { KMC mini- } \\
\text { mum } 6 \text { hours/ } \\
\text { day. }\end{array}$ & $\begin{array}{l}\text { Standard treatment } \\
\text { consists of maintenance } \\
\text { under a heater or an } \\
\text { incubator }\end{array}$ & $\begin{array}{l}\text { Weight } \\
\text { gain }\end{array}$ \\
\hline $\begin{array}{l}\text { Comparison of skin- } \\
\text { to-skin contact with } \\
\text { standard contact in } \\
\text { low-birth-weight } \\
\text { infants who are } \\
\text { breast-fed }\end{array}$ & Bier et al., & $\begin{array}{l}\text { 1996/ } \\
\text { Rhode } \\
\text { Island AS }\end{array}$ & $\mathrm{RCT}$ & 25 & 25 & $\begin{array}{l}\text { Premature } \\
\text { infants } \\
<1500 \text { g, } \\
34 \text { to } 36 \\
\mathrm{mg}\end{array}$ & $\begin{array}{l}\text { KMC for } 1 \\
\text { hour }\end{array}$ & $\begin{array}{l}\text { Babies are dressed, } \\
\text { wrapped in blankets, and } \\
\text { placed in the mother's } \\
\text { arms }\end{array}$ & $\begin{array}{l}\text { Weight } \\
\text { gain }\end{array}$ \\
\hline $\begin{array}{l}\text { Short duration of } \\
\text { skin-to-skin contact: } \\
\text { Effects on growth } \\
\text { and breastfeeding }\end{array}$ & Boo et al., & $\begin{array}{l}\text { 2007/ } \\
\text { Kuala } \\
\text { Lumpur, } \\
\text { Malaysia }\end{array}$ & $\mathrm{RCT}$ & 64 & 62 & $\begin{array}{l}\text { Premature } \\
\text { infants } \\
<1501 \mathrm{~g}, \\
\text { aged }<36 \\
\text { weeks }\end{array}$ & $\begin{array}{l}\text { Skin to skin } \\
\text { contact for } 1 \\
\text { hour/day }\end{array}$ & $\begin{array}{l}\text { Not treated with } \\
\text { Kangaroo Mother Care }\end{array}$ & $\begin{array}{l}\text { Weight } \\
\text { gain }\end{array}$ \\
\hline $\begin{array}{l}\text { Kangaroo Mother } \\
\text { Care in Kangaroo } \\
\text { ward for improving } \\
\text { the growth and } \\
\text { breastfeeding out- } \\
\text { comes when reach- } \\
\text { ing term gestational } \\
\text { age in very low birth } \\
\text { weight infants }\end{array}$ & $\begin{array}{l}\text { Ghavane } \\
\text { et al., }\end{array}$ & $\begin{array}{l}2012 / \\
\text { India }\end{array}$ & $\mathrm{RCT}$ & 68 & 68 & $\begin{array}{l}\text { Premature } \\
\text { infants } \\
<1500 \text { g, } \\
\text { aged } \leq 30 \\
\text { weeks }\end{array}$ & $\begin{array}{l}\text { KMC mini- } \\
\text { mum } 8 \text { hours/ } \\
\text { day }\end{array}$ & $\begin{array}{l}\text { Incubators/warmers are } \\
\text { cared for in the } \\
\text { intermediate care unit by } \\
\text { nurses under constant } \\
\text { supervision. }\end{array}$ & $\begin{array}{l}\text { Weight } \\
\text { gain }\end{array}$ \\
\hline $\begin{array}{l}\text { A comparison of } \\
\text { kangaroo mother } \\
\text { care and conven- } \\
\text { tional cuddling care }\end{array}$ & $\begin{array}{l}\text { Roberts et } \\
\text { al., }\end{array}$ & $\begin{array}{l}2000 / \\
\text { Australia }\end{array}$ & $\mathrm{RCT}$ & 16 & 14 & $\begin{array}{l}\text { Premature } \\
\text { infants } \\
\text { aged } \geq \\
30 \mathrm{mg}\end{array}$ & $\begin{array}{l}\text { KMC minimum } \\
2 \text { hours/day }\end{array}$ & $\begin{array}{l}\text { Conventional cuddling } \\
\text { care (CCC) }\end{array}$ & $\begin{array}{l}\text { Weight } \\
\text { gain }\end{array}$ \\
\hline $\begin{array}{l}\text { Kangaroo mother } \\
\text { care in very low }\end{array}$ & $\begin{array}{l}\text { Ramanath } \\
\text { an et al., }\end{array}$ & $\begin{array}{l}\text { 2001/ } \\
\text { India }\end{array}$ & $\mathrm{RCT}$ & 14 & 14 & $\begin{array}{l}\text { Premature } \\
\text { infants }\end{array}$ & $\begin{array}{l}\text { KMC minimum } \\
4 \text { hours/day }\end{array}$ & $\begin{array}{l}\text { Conventional Care } \\
\text { incubator or open care }\end{array}$ & $\begin{array}{l}\text { Weight } \\
\text { gain }\end{array}$ \\
\hline
\end{tabular}


Pravitasari et al./ The Effect of Kangaroo Mother Care in Increasing Body Weight

birth weight infants

Randomized control

trial of kangaroo

Acharya et 2014/

mother care in low

birth weight babies

at a tertiary level

hospital

Kangaroo mother

care for low birth

weight babies: A

randomized control-

led trial in a tertiary

care hospital of

Bangladesh

Kangaroo mother

care for low birth-

weight infants: a

randomized control-

led trial in different

settings

Kangaroo Mother

Care for low birth-

weight infants: a

randomized control-

led trial in different

settings

Kangaroo mother

care for low birth-

weight infants: a

randomized con-

trolled trial in diffe-

$\mathrm{h}$

et al.,
RCT 63

Nepal

$\begin{array}{ll}\text { Rahman } & \text { 2017/ } \\ \text { et al., } & \text { Banglades } \\ & \text { h }\end{array}$

$\mathrm{RCT}$
Sarjono et 1998/
al., Indonesia

RCT

52

54

$\begin{array}{ll}\text { Worku et } & 1998 / \\ \text { al., } & \text { Ethiopia }\end{array}$

Echverria 1998/

Mexico

RCT

47

32
$<1500 \mathrm{~g}$

Premature

infants

$<2000 \mathrm{~g}$

6 hours/day

system

Conventional Care

dressed, covered and

cared for with their

mother

Conventional Care cared

for under an infant

warmer

infants

$\mathrm{KMC}$

$1250 \mathrm{~g}$ to

$1800 \mathrm{~g}$

aged $>30$

to $<35$

weeks

Premature KMC average

infants

1000 -

20 hours/day

$1999 \mathrm{~g}$

Premature KMC average infants100 20 hours/day

o -1999 g

Premature

infants

KMC average

20 hours/day

Conventional Care

Conventional Care

Weight gain

Weight gain

Weight gain

ent settings 


\section{b. Temperature}

Table 2.Primary study descriptions included in the meta-analysis of the effect of KMC on temperature in preterm infants

\begin{tabular}{|c|c|c|c|c|c|c|c|c|c|}
\hline \multirow{2}{*}{ Title } & \multirow{2}{*}{ Author } & \multirow{2}{*}{$\begin{array}{c}\text { Year/ } \\
\text { Country }\end{array}$} & \multirow{2}{*}{$\begin{array}{c}\text { Study } \\
\text { Design }\end{array}$} & \multicolumn{2}{|c|}{ Total Sample } & \multirow{2}{*}{ Population } & \multirow{2}{*}{ Intervention } & \multirow{2}{*}{ Comparison } & \multirow{2}{*}{ Outcome } \\
\hline & & & & KMC & Control & & & & \\
\hline $\begin{array}{l}\text { Effect of kanga- } \\
\text { roo mother care } \\
\text { on physical } \\
\text { growth, breast- } \\
\text { feeding and its } \\
\text { acceptability }\end{array}$ & $\begin{array}{l}\text { Gathwala } \\
\text { et al., }\end{array}$ & $\begin{array}{l}\text { 2010/ } \\
\text { India }\end{array}$ & RCT & 50 & 50 & $\begin{array}{l}\text { Premature } \\
\text { infantsr } \\
<1800 \mathrm{~g}\end{array}$ & $\begin{array}{l}\text { KMC } \\
\text { minimum } 6 \\
\text { hours/day }\end{array}$ & $\begin{array}{l}\text { Standard treat- } \\
\text { ment consists of } \\
\text { maintenance } \\
\text { under a warmer } \\
\text { or an incubator }\end{array}$ & Temperature \\
\hline $\begin{array}{l}\text { A randomized } \\
\text { controlled trial of } \\
\text { early kangaroo } \\
\text { care for preterm } \\
\text { infants: Effects } \\
\text { on temperature, } \\
\text { weight, behavior, } \\
\text { and acuity }\end{array}$ & $\begin{array}{l}\text { Chwo et } \\
\text { al., }\end{array}$ & $\begin{array}{l}2002 / \\
\text { Taiwan }\end{array}$ & RCT & 17 & 17 & $\begin{array}{l}\text { Premature } \\
\text { infants aged } \\
34 \text { to } 36 \\
\text { weeks }\end{array}$ & $\begin{array}{l}\text { KMC } \\
\text { minimum } 1 \\
\text { hour }\end{array}$ & $\begin{array}{l}\text { Mothers carry } \\
\text { their babies } \\
\text { wrapped in } \\
\text { blankets. }\end{array}$ & Temperature \\
\hline $\begin{array}{l}\text { A comparison of } \\
\text { kangaroo mother } \\
\text { care and conven- } \\
\text { tional cuddling } \\
\text { care }\end{array}$ & $\begin{array}{l}\text { Roberts et } \\
\text { al., }\end{array}$ & $\begin{array}{l}\text { 2000/ } \\
\text { Australia }\end{array}$ & $\mathrm{RCT}$ & 16 & 14 & $\begin{array}{l}\text { Premature } \\
\text { infantsaged } \\
\geq 30 \text { weeks }\end{array}$ & $\begin{array}{l}\text { KMC } \\
\text { minimum } 2 \\
\text { hours/day }\end{array}$ & $\begin{array}{l}\text { Conventional } \\
\text { cuddling Care } \\
\text { (CCC) }\end{array}$ & Temperature \\
\hline $\begin{array}{l}\text { Randomized con- } \\
\text { trolled trial of } \\
\text { kangaroo care: } \\
\text { Cardiorespiratory } \\
\text { and thermal } \\
\text { effects on healthy } \\
\text { preterm infants }\end{array}$ & $\begin{array}{l}\text { Ludington- } \\
\text { Hoe et al., }\end{array}$ & $\begin{array}{c}\text { 2004/ } \\
\text { USA }\end{array}$ & RCT & 11 & 13 & $\begin{array}{l}\text { Premature } \\
\text { infantsaged } \\
33 \text { to } 35 \\
\text { weeks }\end{array}$ & $\begin{array}{l}\text { KMC for } 2 \text { to } 3 \\
\text { hours } \\
\text { continuously }\end{array}$ & $\begin{array}{l}\text { Conventional } \\
\text { Care NICU/ } \\
\text { incubator } \\
\text { standard }\end{array}$ & Temperature \\
\hline
\end{tabular}




\section{Study Quality Assessment}

Assessment of Study Quality using the Critical Appraisal CEBM (Center For Evidence-Based Medicine)

Table 3. Study Quality Assessment of the Effect of Kangaroo Mother Care on Weight Gain in Premature Infants

\begin{tabular}{|c|c|c|c|c|c|c|}
\hline Lists of Question & $\begin{array}{l}\text { Gathwala } \\
\text { et al., } 2010\end{array}$ & $\begin{array}{c}\text { Bier et al., } \\
1996\end{array}$ & $\begin{array}{l}\text { Boo et al., } \\
2007\end{array}$ & $\begin{array}{l}\text { Ghavane et } \\
\text { al., } 2012 \\
\end{array}$ & $\begin{array}{l}\text { Roberts et } \\
\text { al., 2000 }\end{array}$ & $\begin{array}{l}\text { Ramanathan } \\
\text { et al., 2001 }\end{array}$ \\
\hline Does this study address a clear research focus? & 1 & 1 & 1 & 1 & 1 & 1 \\
\hline $\begin{array}{l}\text { Is the Randomized Controlled Trial research method } \\
\text { suitable for answering research questions? }\end{array}$ & 1 & 1 & 1 & 1 & 1 & 1 \\
\hline $\begin{array}{l}\text { Are there enough subjects in the study to establish } \\
\text { that the findings were not made by chance? }\end{array}$ & 1 & 1 & 1 & 1 & o & o \\
\hline $\begin{array}{l}\text { Are subjects randomly allocated to the experimental } \\
\text { and control groups? If not, can this cause bias? }\end{array}$ & 1 & 1 & 1 & 1 & 1 & 1 \\
\hline Are inclusion/exclusion criteria used?? & 1 & 1 & 1 & 1 & 1 & 1 \\
\hline $\begin{array}{l}\text { Were the two groups comparable at the beginning of } \\
\text { the study? }\end{array}$ & 1 & 1 & 1 & o & 1 & 1 \\
\hline Do objective and unbiased outcome criteria are used? & 1 & 1 & 1 & 1 & 1 & 1 \\
\hline $\begin{array}{l}\text { Are objective and validated measurement methods } \\
\text { used to measure the results? If not, were the results } \\
\text { scored by someone who did not know the group } \\
\text { assignment (i.e. were the assessments blinding)? }\end{array}$ & 1 & 1 & 1 & 1 & 1 & 1 \\
\hline Is the effect size practically relevant? & 1 & 1 & 1 & 1 & 1 & 1 \\
\hline $\begin{array}{l}\text { How precise is the estimated effect? Is there a } \\
\text { confidence interval? }\end{array}$ & 1 & 1 & 1 & o & o & 1 \\
\hline $\begin{array}{l}\text { Could there be confounding factors that have not } \\
\text { been taken into account such as intake of nutrition, } \\
\text { birth weight, gestational age? }\end{array}$ & o & 1 & 1 & 1 & 1 & 1 \\
\hline Are the results applicable to your research? & 1 & 1 & 1 & 1 & 1 & 1 \\
\hline Total & 11 & 12 & 12 & 10 & 10 & $\mathbf{1 1}$ \\
\hline
\end{tabular}

Answer: $1=$ Yes, $0=$ No 


\begin{tabular}{|c|c|c|c|c|c|}
\hline Lists of Question & $\begin{array}{l}\text { Achrya et } \\
\text { al., } 2014\end{array}$ & $\begin{array}{c}\text { Rahman } \\
\text { et al., } 2017\end{array}$ & $\begin{array}{l}\text { Sarjono et } \\
\text { al., } 1998\end{array}$ & $\begin{array}{l}\text { Worku et } \\
\text { al., } 1998\end{array}$ & $\begin{array}{r}\text { Echverria } \\
\text { et al., } 1998\end{array}$ \\
\hline Does this study address a clear research focus? & 1 & 1 & 1 & 1 & 1 \\
\hline $\begin{array}{l}\text { Is the Randomized Controlled Trial research method suitable } \\
\text { for answering research questions? }\end{array}$ & 1 & 1 & 1 & 1 & 1 \\
\hline $\begin{array}{l}\text { Are there enough subjects in the study to establish that the } \\
\text { findings were not made by chance? }\end{array}$ & 1 & 1 & 1 & 1 & 1 \\
\hline $\begin{array}{l}\text { Are subjects randomly allocated to the experimental and } \\
\text { control groups? If not, can this cause bias? }\end{array}$ & 1 & 1 & 1 & 1 & 1 \\
\hline Are inclusion/exclusion criteria used?? & 1 & 1 & 1 & 1 & 1 \\
\hline $\begin{array}{l}\text { Were the two groups comparable at the beginning of the } \\
\text { study? }\end{array}$ & 1 & 1 & 1 & 1 & $\mathrm{O}$ \\
\hline Do objective and unbiased outcome criteria are used? & 1 & 1 & 1 & 1 & 1 \\
\hline $\begin{array}{l}\text { Are objective and validated measurement methods used to } \\
\text { measure the results? If not, were the results scored by } \\
\text { someone who did not know the group assignment (i.e. were } \\
\text { the assessments blinding)? }\end{array}$ & 1 & 1 & 1 & 1 & 1 \\
\hline Is the effect size practically relevant? & 1 & 1 & 1 & 1 & 1 \\
\hline $\begin{array}{l}\text { How precise is the estimated effect? Is there a confidence } \\
\text { interval? }\end{array}$ & $\mathrm{O}$ & 1 & 1 & 1 & 1 \\
\hline $\begin{array}{l}\text { Could there be confounding factors that have not been taken } \\
\text { into account such as intake of nutrition, birth weight, } \\
\text { gestational age? }\end{array}$ & 1 & $\mathrm{O}$ & 1 & 1 & 1 \\
\hline Are the results applicable to your research? & 1 & 1 & 1 & 1 & 1 \\
\hline Total & 11 & 11 & 12 & 12 & $\mathbf{1 1}$ \\
\hline
\end{tabular}

Answer: $1=$ Yes, $\mathrm{O}=$ No 
Table 4. Assessment of the Quality of Study on the Effect of Kangaroo Mother Care on Increasing Temperature in Premature Infants using the Critical Appraisal CEBMa (Center For Evidance-Based Medicine)

\begin{tabular}{|c|c|c|c|c|}
\hline Lists of Question & $\begin{array}{l}\text { Gathwala et } \\
\text { al., } 2010\end{array}$ & $\begin{array}{l}\text { Chwo et al., } \\
\quad 2002\end{array}$ & $\begin{array}{l}\text { Roberts et } \\
\text { al., 200o }\end{array}$ & $\begin{array}{l}\text { Ludington-Hoe } \\
\text { et al., } 2004\end{array}$ \\
\hline Does this study address a clear research focus? & 1 & 1 & 1 & 1 \\
\hline $\begin{array}{l}\text { Is the Randomized Controlled Trial research method suitable for } \\
\text { answering research questions? }\end{array}$ & 1 & 1 & 1 & 1 \\
\hline $\begin{array}{l}\text { Are there enough subjects in the study to establish that the findings } \\
\text { were not made by chance? }\end{array}$ & 1 & o & o & o \\
\hline $\begin{array}{l}\text { Are subjects randomly allocated to the experimental and control } \\
\text { groups? If not, can this cause bias? }\end{array}$ & 1 & 1 & 1 & 1 \\
\hline Are inclusion/exclusion criteria used?? & 1 & 1 & 1 & 1 \\
\hline Were the two groups comparable at the beginning of the study? & & 1 & & 1 \\
\hline Do objective and unbiased outcome criteria are used? & 1 & 1 & 1 & 1 \\
\hline $\begin{array}{l}\text { Are objective and validated measurement methods used to measure } \\
\text { the results? If not, were the results scored by someone who did not } \\
\text { know the group assignment (i.e. were the assessments blinding)? }\end{array}$ & 1 & 1 & 1 & 1 \\
\hline Is the effect size practically relevant? & 1 & 1 & 1 & 1 \\
\hline How precise is the estimated effect? Is there a confidence interval? & o & o & o & o \\
\hline $\begin{array}{l}\text { Could there be confounding factors that have not been taken into } \\
\text { account such as room temperature and mother's body temperature }\end{array}$ & o & o & o & o \\
\hline Are the results applicable to your research? & 1 & 1 & 1 & 1 \\
\hline Total & 10 & 9 & 9 & 9 \\
\hline
\end{tabular}

Answer: $1=$ Yes, $0=$ No 
Pravitasari et al./ The Effect of Kangaroo Mother Care in Increasing Body Weight

\section{Forest Plot}

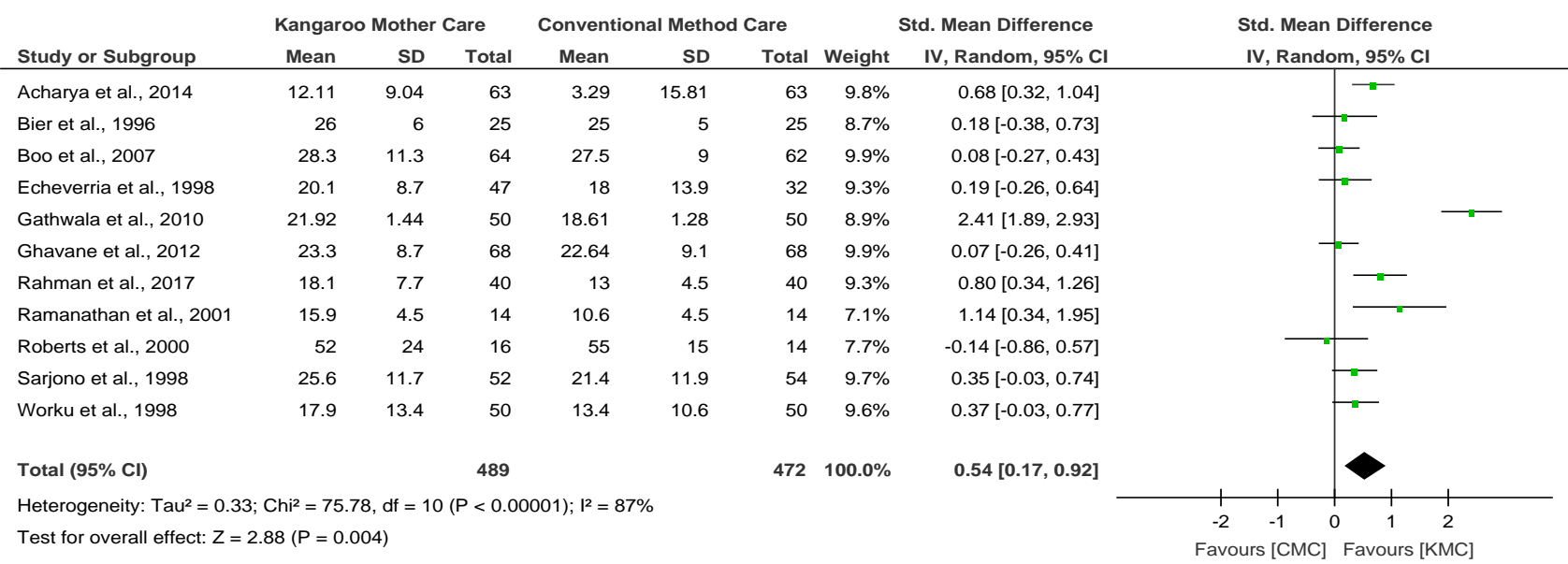

Figure 3. Meta-analysis forest plot of the effect of Kangaroo Mother Care on Weight Gain in Premature Infants

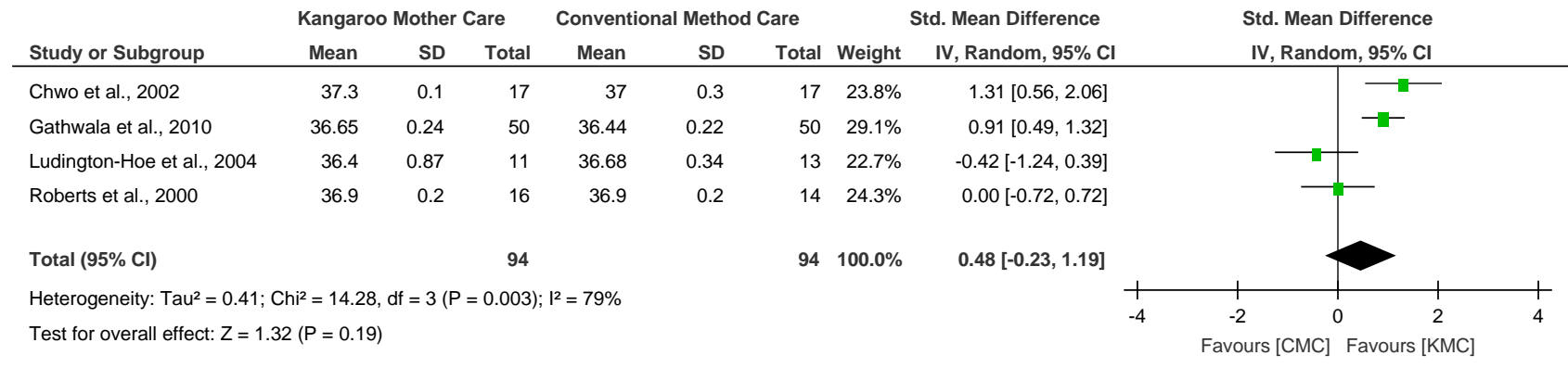

Figure 4. Meta-analysis forest plot of the effect of Kangaroo Mother Care on Temperature in Premature Infants

Based on the results of the analysis in Figure 3, it can be seen that 11 articles reported that Kangaroo Mother Care increased body weight in premature infants. Based on the analysis, there was high heterogeneity between experiments $\left(\mathrm{I}^{2}=87 \% ; \mathrm{p}<0.001\right)$ so that the Random
Effect Model (REM) was used. The provision of Kangaroo Mother Care care interventions increased body weight in preterm infants higher than the conventional method care (Standardized Mean Difference $=0.54 ; 95 \% \mathrm{CI}=0.17$ to $0.92 ; \mathrm{p}=$ 0.004). 


\section{Funnel Plot}

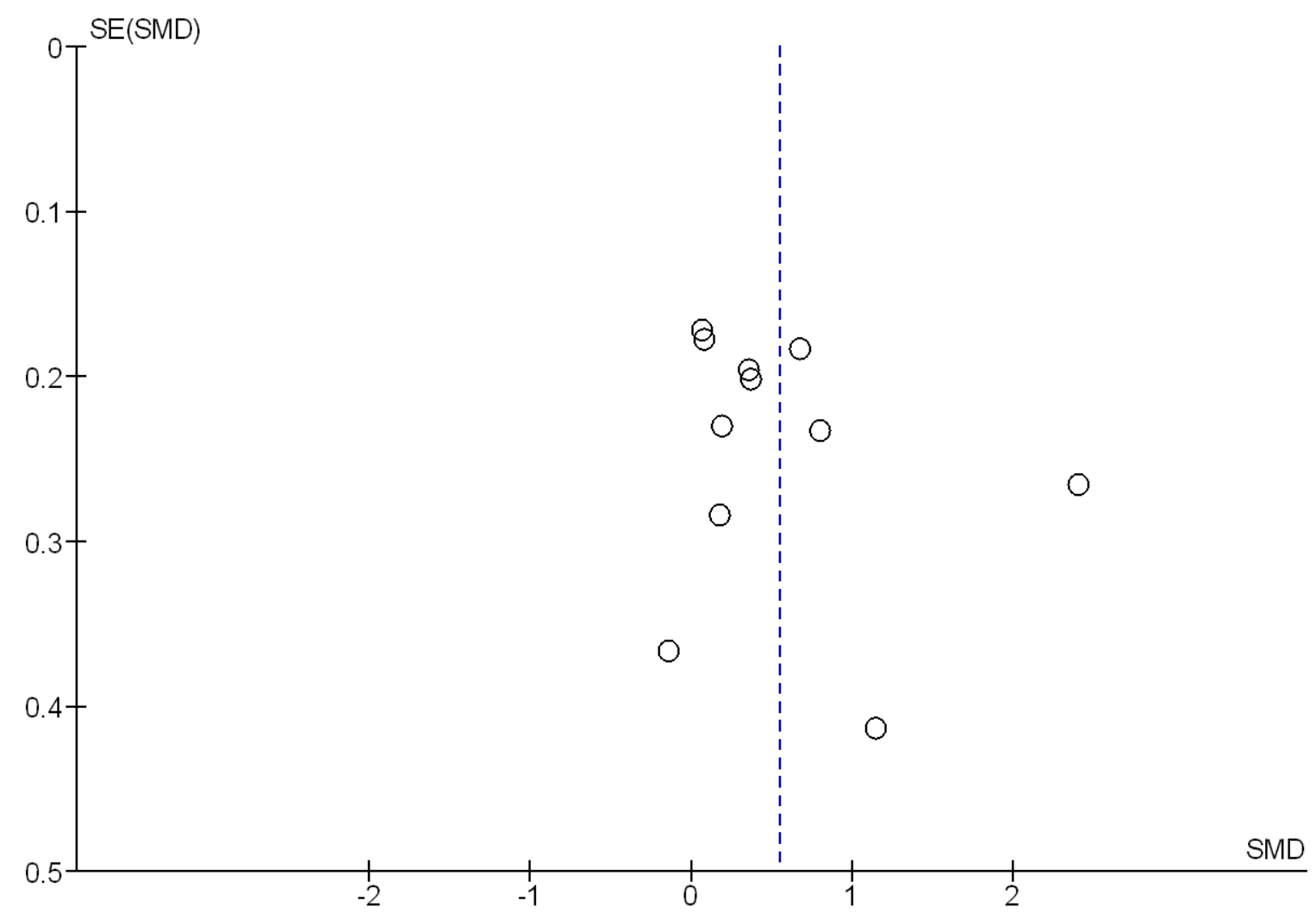

Figure 5. Meta-analysis funnel plot of the effect of Kangaroo Mother Care on Weight Gain in Premature Infants

Based on Figure 5, it showed that there was a publication bias which was characterized by asymmetry of the right and left plots and did not form an inverted funnel where 4 plots were on the right and 7 were plots. The plot on the left of the graph has a standard error between 0.1 and 0.4 , while the plot on the right of the graph has a standard error between 0.1 and 0.4 .

Meta analysis can be seen through the forest plot (Figure 4) which showed that the provision of Kangaroo Mother Care care interventions increased the temperature in preterm infants higher than the Conventional Method Care, statistically not significant (Standardized Mean Difference= $0.48 ; 95 \% \mathrm{CI}=-0.23$ to $1.19 ; \mathrm{p}=0.190$ ). heterogeneity between experiments showed $\mathrm{I}^{2}=79 \% ; \mathrm{p}=0.003$ (Random Effect Model). 


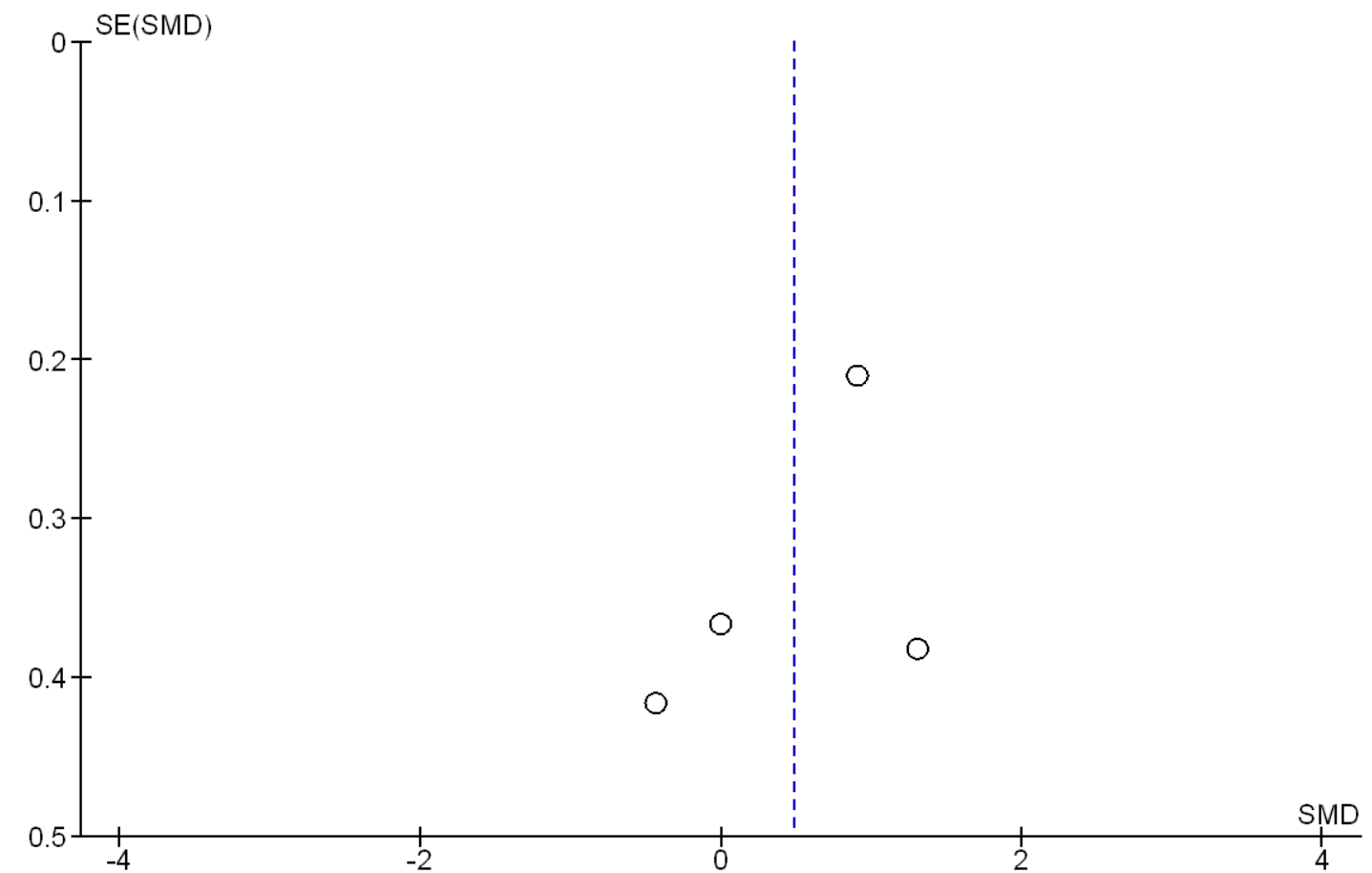

\section{Figure 6. Meta-analysis Forest plot of the effect of Kangaroo Mother Care on Increased Temperature in Premature Infants}

Figure 6 showed that there was no publication bias which was indicated by a balance between the right plot and the left plot where there were 2 plots on the right and 2 plots on the left, forming an inverted funnel. The plot on the left of the graph has a standard error between 0.3 and 0.5 , while the plot on the right of the graph has a standard error between 0.2 and 0.4 .

\section{DISCUSSION}

This systematic review and meta-analysis study raised the theme of the effect of Kangaroo Mother Care on increasing body weight and temperature in preterm infants.

Systematic review and meta-analysis in this study used study that controlled confounding factors which could be seen from the inclusion criteria of the study, which was using the Randomized Controlled Trial design and the statistical results reported were Mean Difference (MD) and Standard Deviation (SD). The analysis was carried out on 1,149 preterm babies and the results of the analysis were presented in the form of a forest plot which showed visually the amount of variation (heterogeneity) (Akobeng, 2005 in Murti, 2018), and the possibility of bias was presented with a funnel plot which showed the relationship between the effect size of the study and the sample size of the various studies under study, which can be measured in various different ways (Murti, 2018).

\section{Kangoroo mother care on pre- mature infants' birth weight}

Based on the results of the analysis of 11 articles regarding Kangoroo Mother Care on weight gain in premature babies, it was reported that there was high heterogeneity between experiments $\left(\mathrm{I}^{2}=87 \%\right.$; $\left.\mathrm{p}<0.001\right)$ so that the Random Effect Model (REM) was used. Kangaroo Mother Care increases body weight in preterm infants was higher than Conventional Method Care (Standardized Mean Difference $=0.54$; CI95\% $=0.17$ to $0.92 ; \mathrm{p}=0.004$ ). 
Kangoroo Mother Care has several advantages over conventional care, some of which are breastfeeding, maternal trust and emotional bonding, and cost-effectiveness (WHO, 2003).

With Kangoroo Mother Care, breastfeeding takes longer, milk production is more stable, the amount of breastfeeding per day increases, and confidence in breastfeeding increases so that it can indirectly increase the amount of breast milk intake in premature infants and can increase their body weight.

Several studies have shown the effect of Kangoroo Mother Care on weight gain in premature babies. One of them is a study by Chiu and Anderson (2009) entitled Effect of early skin-to-skin contact on motherpreterm infant interaction through 18 months: Randomized controlled trial with a sample size of 52 in the KMC group and 48 in the control group showed a mean value of 2288 and the standard deviation of 385 in the KMC group and in the control group, the mean is 2262 and standard deviation is 438.

Another study by Sharma et al., (2018) conducted on 79 infants with low birth weight showed a significantly better weight gain after treatment during hospital stay. The mean value is 24.21 and a standard deviation of 6.4 in the experimental group and in the control group the mean is 20.88 and standard deviation is 5.1.

\section{Kangoroo mother care on prema- ture infants' temperature}

Based on the results of the analysis of 4 articles regarding Kangoroo Mother Care towards increasing temperature in premature babies, it is reported that there was high heterogeneity between experiments $\left(\mathrm{I}^{2}=79 \% ; \mathrm{p}=0.003\right)$ so that the Random Effect Model (REM) was used. Kangaroo Mother Care increased the temperature in preterm infants higher than conventional method care, statistically insignificant (Standardized Mean Difference $=0.48$; 95\% CI $=-0.23$ to $1.19 ; \mathrm{p}=0.190$ ).

The mother's body temperature is an efficient and inexpensive source of heat and can provide a warm environment for the baby. A stable mother's body temperature is safer than the risk of hypothermia and hyperthermia that can be experienced by babies when using incubators with poor management (Alisjahbana et al., 2017). As long as the baby is in Kangaroo Mother Care, there will be a thermal synchrony between the mother and the baby, namely the mother's body temperature increases or decreases according to the need to keep the baby within a neutral body temperature limit (36.5-37.5oC), so that it can indirectly create body temperature and the baby will become more stable(Margaretha, 2016).

Based on the research of Kokilavani (2013), for the first day of pre-observation Kangaroo Mother Care was an average of 35.4 and a standard deviation of 0.256 after treatment the mean was 36.6 and a standard deviation of 0.316 . On day 1 , the mean difference was $1.2^{\circ} \mathrm{C}$ after kangaroo care. On the 3 rd day of pre-observation, Kangaroo Mother Care mean was 36.4 and standard deviation was 0.197 , and on postobservation the mean was 37.4 and SD was o.168. The average difference was $1^{\circ} \mathrm{C}$ which indicates that kangaroo care is much more effective.

The meta-analysis of 11 articles concluded that Kangaroo Mother Care increased body weight in preterm infants higher than the conventional method of care (Standardized Mean Difference $=0.54 ;$ 95\% $\mathrm{CI}=0.17$ to $0.92 ; \mathrm{p}=0.004)$. This meta-analysis combined 11 primary studies using a Randomized Controlled Trial design from India, Nepal, Bangladesh, Malaysia, Indonesia, Australia, Mexico, Ethiopia. 
Meta-analysis in 4 articles concluded that Kangaroo Mother Care increased the temperature in preterm infants higher than conventional method care, and it was statistically insignificant (Standardized Mean Difference $=0.48 ; 95 \% \mathrm{CI}=-0.23$ to 1.19; $\mathrm{p}=0.190)$. This meta-analysis combined 4 primary studies using a Randomized Controlled Trial design from India, Taiwan, Australia and the United States.

\section{AUTHOR CONTRIBUTION}

Ines Ratni Pravitasariis the main researcher who selected a topic, exploreed and collected study data. Bhisma Murti has a role in analyzing the data and Vitri Widyaningsih has a role in reviewing study documents.

\section{CONFLICT OF INTEREST}

There was no conflict of interest.

\section{FUNDING AND SPONSORSHIP}

This study used personal fund of the main researcher.

\section{ACKNOWLEDGEMENT}

We are very thankful to the database providers of PubMed, Google Scholar and Science Direct.

\section{REFERENCE}

Acharya N, Singh RR, Bhatta NK, Poudel P (2014). Randomized control trial of Kangaroo Mother Care in low birth weight babies at a tertiary level hospital. Journal of Nepal Paediatric Society, 34(1): 18-23. doi: 10.3126/jnps.v34i1.8960.

Alisjahbana A, Usman A, Irawaty S, Triyati A (2017). Prevention of hypothermia of low birth infants using the kangaroo method. Paediatrica Indonesiana. 38(9-10): 205. doi: 10.14238/pi38.910.1998.205-14.

Boo NY, Jamli FM (2007) Short duration of skin-to-skin contact: Effects on growth and breastfeeding. $J$ Paediatr Child $H$. 43(12): 831-836. doi: 10.1111/j.14401754.2007.01198.x.

Bailey S (2012). Kangaroo mother care. Brit J Hosp Med. 73(5): 278-281. doi: 10.12968/hmed.2012.73.5.278.

Cattaneo A, Davanzo R, Worku B, Surjono A, Echeverria M, Bedri A, Haksari E et al., (1998). Kangaroo mother care for low birthweight infants: A randomized controlled trial in different settings. Acta Paediatr. 87(9): 976-985. doi: 10.1080/080352598750031653.

Chiu SH, Anderson GC (2009). Effect of early skin-to-skin contact on motherpreterm infant interaction through 18 months: Randomized controlled trial, Int J Nurs Stud. 46(9): 1168-1180. doi: 10.1016/j.ijnurstu.2009.03.005.

Gathwala G, Singh J, Singh B (2010). Effect of KangarooMother Care on physical growth, breastfeeding and its acceptability. Tropical Doctor. 40: 199203.

Ghavane S, Subramanian S, Gaddam P, Kandraju H, Thumalla S. (2012). Kangaroo Mother Care in Kangaroo ward for improving the growth and breastfeeding outcomes when reaching term gestational age in very low birth weight infants. Acta Paediatr. 101(12). doi: 10.1111/apa.12023.

Kokilavani S (2013). Effect of kangaroo mother care on neonatal temperature and weight among newborns. Nurs $\mathrm{J}$ Ind. 104(2): 31-35. Available at: http://search.proquest.com/docview/ 1536919751 ? accountid $=38628$.

Liu L, Oza S, Hogan D, Chu Y, Perin J, Zhu J, Lawn JE, Cousens S, Mathers C, Black RE (2016). Global, regional, and national causes of under- 5 mortality in 2000-15: an updated systematic analysis with implications for the Sustainable Development Goals. The 
Lancet. 388(10063): 3027-3035. doi: 10.1016/So140-6736(16)31593-8.

Ludington-Hoe SM. et al. (2004) Randomized controlled trial of kangaroo care: cardiorespiratory and thermal effects on healthy preterm infants. Neonatal network: NN. 23(3): 39-48. doi: 10.1891/07300832.23.3.39.

Margaretha SL (2016). Metoda kanguru pada perawatan bayi berat lahir rendah (Kangaroo method in the care of low birth weight infants), Sari Pediatri, 8(3): 181. doi: 10.14238/sp8.3.2006.181-7.

McCall EM, Alderdice F, Halliday HL, Vohra S, Johnston L (2018). Interventions to prevent hypothermia at birth in preterm and/or low birth weight infants. Cochrane Database Syst Rev. 2018 (2): CDoo4210. doi: 10.1002/14651858.CDoo4210.pub5.

Mullany LC, Katz J, Khatry SK, LeClerq SC, Darmstadt GL, Tielsch JM (2010). Neonatal hypothermia and associated risk factors among newborns of Southern Nepal. BMC Med. 8, 43 (2010). doi: 10.1186/1741-7015-8-43.

Murti B (2018). Prinsip dan Metode Riset Epidemiologi. Edisi ke 5 (Epidemiological Research Principles and $\mathrm{Me}-$ thods. 5th edition). Surakarta: Program Studi Ilmu Kesehatan Masyarakat, Program Pascasarjana, Universitas Sebelas Maret.

Ramanathan K, Paul V K, Deorari AK, Taneja U, George G. (2001) Kangaroo mother care in very low birth weight infants. Indian $J$ Pediatr. 68(11): 1019-1023. doi: 10.1007/BFo2722345.

Ramani Met al., (2018). Kangaroo mother care for the prevention of neonatal hypothermia: A randomised controlled trial in term neonates.Arch Dis Child. 103(5): 492-497. doi: 10.1136/archdischild-2017-313744.

Roberts KL, Paynter C, McEwan B (2000). A comparison of kangaroo mother care and conventional cuddling care. Neonatal network: NN, 19(4): 31-35. doi: 10.1891/0730-0832.19.4.31.

Sharma D,Murki S, Oleti TP (2018). Study comparing "Kangaroo Ward Care" with "Intermediate Intensive Care" for improving the growth outcome and cost effectiveness: Randomized control trial. J Matern-Fetal Neo M. 31(22): 2986-2993. doi: 10.1080/14767058.2017.1359832.

Swarnkar K dan Vagha J (2016). Effect of kangaroo mother care on growth and morbidity pattern in low birth weight infants.Journal of Krishna Institute of Medical Sciences University. 5(1): 9199.

Taheri PAet al., (2018). The effect of a short course of moderate pressure sunflower oil massage on the weight gain velocity and length of NICU stay in preterm infants.Infant Behav Dev. Elsevier, 50(January 2017): 22-27. doi: 10.1016/j.infbeh.2017.11.002.

WHO (2003). Kangaroo mother care: A practical guide.WHO Reproductive Health and Research. 1-48. doi: 10.4038/sljch.v34i1.564. 